\title{
Visual Representativeness in Junior Secondary School English Language Textbooks in Use in Ebonyi State of Nigeria
}

\author{
Chinyere Henrietta Maduabuchi (Corresponding Author) \\ Department of Arts and Social Science Education, Faculty of Education, Ebonyi State University, Abakaliki, Ebonyi State, Nigeria \\ E-mail: ettachimlo@yahoo.com \\ Ekwe, Bernedett \\ Department of Arts and Social Science Education, Faculty of Education, Ebonyi State University, Abakaliki, Ebonyi State, Nigeria
}

Received: 17-09- 2016

doi:10.7575/aiac.ijels.v.4n.4p.58
Accepted: $15-10-2016$

URL: http://dx.doi.org/10.7575/aiac.ijels.v.4n.4p.58

Published: 31-10-2016

\begin{abstract}
Evidence from research findings seems to corroborate with the assertion that the students' constant difficulties in the comprehension of English language texts may have emanated from the limited visual representativeness in most of the recommended textbooks in use in Junior Secondary Schools in Ebonyi State of Nigeria. Textbooks help to equip teachers and learners with broad and factual information concerning what learners should learn by helping them to perform well in the learning environment and in external examinations. This study investigated the types of visual representativeness in Junior Secondary School English Language Textbooks in Ebonyi State vis-à-vis the curriculum content. An exploratory-interpretive design was used in the study. A total of 9 textbooks were selected out of the 18 English language textbooks used in Ebonyi State. The visual representativeness in the textbooks were analyzed using content and qualitative analysis. Simple Percentage and frequency counts were used in the interpretation of visual representativeness in JSS English Language in Use in Ebonyi State. This was done by taking the frequency of the visual representativeness in the textbooks based on the content specification on visual representativeness of topics in the curriculum. The findings showed that the English language textbooks used in junior secondary schools in Ebonyi State of Nigeria adopted decorational, representational, and transformational visuals. It was also found that the visual representativeness in some of the English language textbooks were inadequate. For instance, the Intensive English (books $I$, II, and $I I I$ ), had $14.2 \%, 8 \%$, and 19.2\% under represented visuals respectively, and $85.7 \%, 92 \%$, and $80.8 \%$ adequately represented visuals respectively, In New Concept English (books I, II, III ), we had 14.3\%, 23.8\%, and $29.4 \%$ under represented visuals respectively, and $85.7 \%, 77.1 \%$, and $70.5 \%$ adequately represented visuals respectively and Junior Project English (books I, II, and III) had 20.8\%, 22.7\%, and 26.0 under represented visuals respectively, $12.5 \%, 13.6 \%$, and $13 \%$ not represented visuals respectively and $66.6 \%, 63.6 \%$, and $60.8 \%$ adequately represented visuals respectively. Based on the findings, it is recommended that English language textbooks for junior secondary school should be revised periodically in line with the curriculum content and the trend in the society to ensure more appealing instructional materials.
\end{abstract}

Keywords: Visual Representativeness, English Language Textbooks, in-Use evaluation, Junior Secondary School

\section{Introduction}

Within the scope of this study, visual representativeness means the appearance of visuals in some selected topics in the English language textbooks as approved by the State Universal Basic Education Board and the curriculum. The curriculum stipulates that most of the comprehension passages should be presented visually so as to enhance understanding amongst the learners. This means that passages on "culture, theft, and respect for elders" should be accompanied with visual to make learning concrete. These topics were measured through an enumeration of frequency and percentage count on the number of accompanying visuals that follow each topic of discussion in the selected comprehension passages of the English language under study.

English Language learning in schools is important due to its vastness as an international Language spoken in most countries of the world. In Nigeria, and Ebonyi State in particular, students preparing for Basic Education Certificate Examination (BECE) and Senior School Certificate Examination (SSCE) register English language as a compulsory subject during their examination year. Adequate visual representations in reading comprehension texts facilitate effective reading for adolescent readers. The science of vision tells us something about what goes on in the brain when one is looking at a painting. It remains to explain how this process triggers a properly aesthetic experience. The perception of a work of art unlike the perception of an image, is such that we usually tend to recognize what we see and that aids retention and recall of information, Visual representativeness in the English language textbooks are of various types: decorational, representational, organizational, interpretational and more unconventional one (transformational) 
(Levie, 1987). To present visuals in textbook in a limited form has a great implication in the comprehension of reading passages. This is in contrast to adequate visual representativeness which tend to mirror part or all of the text content and are by far the most commonly used type of illustration. Organizational pictures provide useful structural framework for the text content. While interpretational pictures help to clarify difficult text. Finally, transformational visuals include systematic Mnemonic (Memory enhancing) components that are designed to improve readers' recall of text information. In this instance, information is often recorded to make it more concrete and then related by means of a meaningful interactive illustration (Levie, 1987). Visual books have special appeals and importance for young children in the years before and after they have learnt to read, but many picture books are also suited for older or even adult readers (Sipe, 1998). Visuals appeal across age groups providing a compelling interplay between the text and illustrations and allowing readers of all ages to enjoy and gain meaning from both adequately represented visual books create a playing field when the reader explores and experiment with relationship between words and the pictures (Mayer, 1994; Sipe, 1998). The English language textbooks are all written in the English Language, which is the lingua franca because it has assumed a national status. It could be learned for instrumental or integrative purposes. When a language is learned instrumentally, the learner needs it functional and communicative purposes. On the other hand, when a language is learned for communicative purposes, the learner is trying to identify more closely with the speech communities which use the language.

In Nigeria, it is necessary for everyone to acquire the Language correctly and properly to avoid communication gap (Baldeh, 2010). In language learning, good passes in the subject show the extent of students' understanding of the various aspects of English Language; that is the comprehension and other aspects of the Language. Poor performances in English Language examination show short fall in students' learning ability of the various aspects involved especially in reading. Most times, students find it difficult to read, understand and appreciate the various aspects of English Language.

This could be attributed to the limited inclusion of visuals in the English Language textbooks used in junior secondary schools, which highlights the inclusion of adequate visuals in textbooks as a good technique for effective comprehension Any reading comprehension in Junior Secondary School without appropriate may constitute a constraint to faster mastery of contents especially in the teaching of abstract issues. Students may appear alienated from a passage when there is a limited visual representation of content issues.

English language is important in teaching and learning and Performances of students in English language in School Certificate Examination as attested by the West African Examination Council (WAEC) Chief Examiners reports (2013) have not been satisfactory. As a result of the report, there is an important need to survey English language textbooks used in Junior Secondary Schools as one of the culprits to the poor performances in question. Textbooks perform important role in the teaching and learning process. English language textbooks help students to study at their leisure time or study before the lesson. These text materials therefore should be written with adequate visual representativeness appropriate for the ages and levels of students using them. Ozongwu (2011) stated that in today's classroom, textbook serves as a guide and gauge and greatly influences how content is delivered considering the currently high level of global technological awareness and emphasis on good education. There is a renewed call for functional and effective English language education in Ebonyi State and in Nigerian society as a whole If English language textbooks have positive influence on students in English language teaching and learning, in Junior Secondary Schools, it became imperative that the contents, pictorial illustrations and what they convey to the students are factual, informative, accurate and up to date. In English language we have certain terminologies and content area that need further elaboration through adequate visual representativeness. In order to encourage students to understand text content, prevent memorization and increase their knowledge and performances, English language textbooks must contain relevant visuals that cover curriculum content (Sipe, 1998).

Curriculum is a print developed for use at all levels of the educational system in Nigeria by the Nigerian Educational Research and Development Council (NERDC) as directed by the National Council on Education (NCE) to re-structure and re-align the existing Primary and Junior Secondary School curricula to meet the targets of the 9- year Basic Education in the context of National Economic Empowerment and Development Strategies (NEEDS) and the Millennium Development Goals (MDG). The curriculum reflects depth, appropriateness, and interrelatedness of the curricula contents. Also, it contains emerging issues which covered value orientation, peace and dialogue including human right education, culture, family life/ HIV and AIDs education and entrepreneurial skills. The curriculum represents the total experiences to which all learners must be exposed, the content performance objectives, activities for both teachers and learners, teaching and learning materials and evaluation guide (Federal Ministry of Education, 2007). English language curriculum embodies the following essential elements: listening and speaking; reading and writing; grammatical accuracy, visual representativeness, and language appreciation through literary works. The main thrust is to foster functional and communicative competences through intensive and extensive practice sessions.

In learning, there is every need for learners to be engaged in the task of learning the curriculum content. This includes exploring facts and points of view from pictorial illustration, reading for improving understanding and answering questions Observing pictorial illustrations in the reading text will help arouse and sustain the student in learning and comprehending facts from the content of the textbooks. Udechukwu (2004) stated that the content of a textbook must be sufficiently needs centered by giving the readers variety of problems, projects and interesting leisure activities in order 
to be activity involved. Practical work arouses and maintains students' interest in learning English language by providing opportunity for participation in investigation and discovery of solutions to problems.

The thrust of this research therefore is to analyze types of visual representations and the extent authors of English language textbooks used visuals in Junior Secondary Schools reading passages. This will help to reveal any imbalance that may likely be observed in the textbooks. When teachers are aware of some facts in the reading textbooks, they will know the action to be taken in teaching their students for better learning in the classroom. Consequently, enhance students' communication ability and improve their performance in internal and external examination.

\subsection{Statement of the Problem}

English language learning for students' effective communication and excellent achievements in examination tends to be the paramount of English language teaching and learning. But West African School Certificate Examinations (WASCE) results of past years showed that students in Ebonyi State who sat for this examination, performed below expectation. This was attested by the report of the Chief Examiners of WASCE (2013) with respect to the students' results. The recorded students' poor performance could be attributed to so many contending factors with teaching material as one of the constraints. One could possibly assume that teaching materials like the English language textbooks could be considered as one of the major contributory factors that enhance learning and students' performance in the subject in both internal and external examinations like Basic Education Certificate Examination (BECE), National Examination Council (NECO) and WASCE. This is based on the fact that knowledge represented through visuals seems to stick in the long term memory spam of the learners; this study investigated the degree of the visual representativeness in the Junior Secondary School textbooks in use in Ebonyi State in terms of:

- The type of visual representativeness in each of the English language textbooks for Junior Secondary Schools.

- The degree of visual representativeness in the JSS English Language textbooks in use in Ebonyi State of Nigeria.

Among some other factors that mar comprehension of passages in the English language, visual representation seems to be very contributive in the performance of students because of its role in ensuring retention and recall of information from texts. Hence, the justification for this study.

\subsection{Purpose of the study}

The purpose of the study was to analyze visuals representation in English language textbooks used in Junior Secondary Schools in Ebonyi State. Specifically, the study sought to:

1. Investigate the types of visual representativeness in the English language textbooks used in Junior Secondary Schools of Ebonyi State Nigeria.

2. Determine the degree of visual representativeness in Junior Secondary School English language textbooks in use in Ebonyi State of Nigeria

\subsection{Research Question}

1. What are the types of visual representativeness in the English language textbooks used in Junior Secondary Schools in Ebonyi State of Nigeria?

2. What is the degrees of visual representativeness in the Intensive English (books I, II and III), New Concept English (books I, II, and III) and Junior Project English (books I, II, and III) in Junior Secondary School English language textbooks in Use in Ebonyi State of Nigeria?

\section{Research Methods}

An exploratory-interpretive design was used in the study, which is a non-experimental design, uses qualitative data and follows interpretive analysis methods (Grotjahn, 1987).

The area of study is Ebonyi State. The State is among the thirty six (36) states of the country Nigeria. It comprises thirteen local government areas and three Education Zones, namely Abakaliki, Onueke and Afikpo Education zones. These three zones have a total number of 205 Government approved Secondary Schools (Ebonyi State Ministry of Education, 2013). English language is taught in all the schools in the area using English language textbooks. But students' results of the past years recorded that students' performances are below expectation WASCE Chief Examiner's Report (2015) In Nigeria, and Ebonyi State in particular, students preparing for Basic Education Certificate Examination (BECE) and Senior School Certificate Examination (SSCE) register English language as a compulsory subject during their examination year. The problem of students' poor performance in English language examination could be attributed to the learning materials among other factors. The aspect of study is visual representation in the comprehension passages and the degree these visuals are represented. This could help to improve students' learning and achievements in internal or external examination.

Eighteen English language textbooks recommended by the State Universal Basic Education Board constituted the bank from which 9 textbooks were selected for this analysis. Purposive sampling technique was used in the selection of these texts based on what is in used in the education zone under study. The instrument used for data collection was qualitative analysis of the visuals content of the textbooks and the visual representation in the textbooks. Against each item, what were analyzed were expected to state the type of visual representativeness, and the degree of this representation with respect to the course content in use. Data collected on visual representativeness in all the textbooks studied were 
grouped into various types of visual representativeness and number visual representativeness. The research questions 1 and 2 were analyzed using content analysis in the form of descriptive statistics. The frequency count was used to assess the visuals representativeness in the textbooks and the degree of visual representativeness in the textbooks in use vis-avis the curriculum specification,

\section{Results}

The results of the study are presented according to the research questions and the hypothesis that guided the study.

3.1 Research Question 1

What are the types of visual representativeness in the English language textbooks in Use in Junior Secondary Schools in Ebonyi State of Nigeria?

The types of visual representativeness used are organizational, interpretational and transformational visuals (Table 1).

Table 1. Types of Visual Representativeness in English Language Textbooks in Use in JSS

\begin{tabular}{|c|c|c|}
\hline Textbook & Types of Visual Representativeness & Examples \\
\hline \multirow[t]{4}{*}{$\begin{array}{l}\text { Intensive English } \\
\text { for J SS1-3 }\end{array}$} & $\begin{array}{l}\text { Visuals on value orientation } \\
\text { (representational) }\end{array}$ & $\begin{array}{l}\text { Doctor at a hospital, a future career, duty to } \\
\text { my country, mass media }\end{array}$ \\
\hline & Family life pictorial (representational) & $\begin{array}{l}\text { Childhood habits, story of life, initiation } \\
\text { accusation, Ngozi and Emeka's quarrel with } \\
\text { a town boy }\end{array}$ \\
\hline & $\begin{array}{l}\text { Human right education visuals } \\
\text { (representational and organizational) }\end{array}$ & $\begin{array}{l}\text { Duty to my country, in the legislature, } \\
\text { treatment of Nigerian Journalist }\end{array}$ \\
\hline & $\begin{array}{l}\text { Entrepreneurial skills visuals } \\
\text { (representational) }\end{array}$ & $\begin{array}{l}\text { Fish production, controlling mosquitoes } \\
\text { school farm }\end{array}$ \\
\hline \multirow[t]{4}{*}{$\begin{array}{l}\text { Junior English } \\
\text { Project for J SS1-3 }\end{array}$} & $\begin{array}{l}\text { Visuals representativeness on value } \\
\text { orientation }\end{array}$ & $\begin{array}{l}\text { Discipline, politeness in social interaction, } \\
\text { women as care givers Entertainment, } \\
\text { experiences in school }\end{array}$ \\
\hline & Social vice & School bullies \\
\hline & Human right education & Importance of first aid, malnutrition \\
\hline & Cultural pictorial & Ancient Kingdom of Benin \\
\hline \multirow[t]{7}{*}{$\begin{array}{l}\text { New Concept English } \\
\text { for J SS 1-3 }\end{array}$} & $\begin{array}{l}\text { Visual representativeness on value } \\
\text { orientation (transformational and } \\
\text { representational) }\end{array}$ & $\begin{array}{l}\text { Personality one admire, negative impact of } \\
\text { the internet on children } \\
\text { Exclusive breastfeeding for infants } \\
\text { Clearing up Nigerian oil pollution } \\
\text { Agriculture }\end{array}$ \\
\hline & $\begin{array}{l}\text { Family life pictorial } \\
\text { (representational and interpretational) }\end{array}$ & Family, diet and nutrition, immunization \\
\hline & Human right education & Effects of war, the civil service, \\
\hline & Entertainment & $\begin{array}{l}\text { Sports, space exploration federal, Safety } \\
\text { corps, sports star }\end{array}$ \\
\hline & Social vices & $\begin{array}{l}\text { Drug abuse, bribery and corruption, drug } \\
\text { trafficking, HIV/AIDs }\end{array}$ \\
\hline & Problems in the society & $\begin{array}{l}\text { HIV/AIDS, flood, increasing rate of } \\
\text { unemployment }\end{array}$ \\
\hline & Cultural heritage & Old Oyo Empire \\
\hline
\end{tabular}

The data presented in table 1 show that Intensive English for Junior Secondary School (books 1-3) have adequate visual representativeness on value orientation, family life, human right education, entrepreneurial skills; Junior Project English (books 1, 2 and 3) visual representativeness on value orientation, social vice, human right education and culture heritage. While New Concept English textbooks 1, 2, and 3 used many visual representativeness on value orientation, family life, human right education, cultural heritage, entertainment, social vice, and problems in the society. It also shows that New Concept English textbooks have varieties of visual representativeness than Intensive English and Junior Project English textbooks. 
What is the degrees of visual representativeness in the Intensive English (books I, II and III), New Concept English (books I, II, and III) and Junior Project English (books I, II, and III) in Junior Secondary School English language textbooks in Use in Ebonyi State of Nigeria?

Table 2a: Frequency and Percentage of Visual Representativeness in English Language Textbooks in Use in JSS in Ebonyi State of Nigeria

\begin{tabular}{|c|c|c|c|c|c|c|c|}
\hline \multirow[t]{2}{*}{$\mathrm{S} / \mathrm{N}$} & \multirow[t]{2}{*}{ Textbooks } & \multicolumn{2}{|c|}{$\begin{array}{l}\text { Under representativeness } \\
\text { of Visuals }\end{array}$} & \multicolumn{2}{|c|}{$\begin{array}{l}\text { Non-representativeness } \\
\text { of Visuals }\end{array}$} & \multicolumn{2}{|c|}{$\begin{array}{l}\text { Representativeness of } \\
\text { Visuals }\end{array}$} \\
\hline & & Frequency & Percentage & Frequency & Percentage & Frequency & Percentage \\
\hline 1. & Intensive English I & 4 & $14.2 \%$ & 0 & 0 & 24 & $85.7 \%$ \\
\hline 2. & Intensive English II & 2 & $8 \%$ & 0 & 0 & 23 & $92 \%$ \\
\hline 3. & Intensive English III & 5 & $19.2 \%$ & 3 & $11.5 \%$ & 18 & $69.2 \%$ \\
\hline 4. & New Concept English I & 3 & $14.3 \%$ & 0 & 0 & 18 & $85.7 \%$ \\
\hline 5. & New Concept English II & 5 & $23.8 \%$ & 0 & 0 & 16 & $77.1 \%$ \\
\hline 6. & New Concept English III & 5 & $29.4 \%$ & 0 & 0 & 12 & $70.5 \%$ \\
\hline 7. & Project English I & 5 & $20.8 \%$ & 3 & $12.5 \%$ & 16 & $66.6 \%$ \\
\hline 8. & Project English II & 5 & $22.7 \%$ & 3 & $13.6 \%$ & 14 & $63.6 \%$ \\
\hline 9. & Project English III & 6 & $26.0 \%$ & 3 & $13 \%$ & 14 & $60.8 \%$ \\
\hline
\end{tabular}

In all the textbooks series as shown in table $2 \mathrm{a}$, there are visual representativeness presented to guide the learners to understanding the reading passages. Intensive English for Junior Secondary Schools series have more visual representation than the other series. It is also observed that in all the selected nine textbooks, there are passages that are underrepresented. Junior English Project book 1, 2and 3 have passages without visuals representativeness which will help the learner understand the passage and encourage such learner appreciate the lesson and the textbook.

Table 2b: Visual Representativeness of the Nine Textbooks.

\begin{tabular}{lllll}
\hline Representativeness & Under represented & Not represented & Represented & Total \\
\hline Frequency & 40 & 12 & 155 & 207 \\
Percentage & $19.3 \%$ & $5.7 \%$ & $74.8 \%$ & $99.8 \%$ \\
\hline
\end{tabular}

The data presented in tables $2 \mathrm{~b}$ show that New Concept English for J SS1, 2 and 3 had visual representativeness, followed by the Intensive English. There are reading passages that were under represented in terms of visual representativeness. Junior Project English (books 1, 2 and 3) have comprehension passages without visual representativeness which will help learners understand the passages and encourage such learners to appreciate the lesson and effect learning.

\section{Discussion}

With regard to the type of visuals representativeness in the English language textbooks in Use in Junior Secondary Schools, the result agrees with the earlier assertion of Mustapha (2012) who discovered inequality in the degree of visual representativeness in some English language texts used in Junior Secondary School in Nigeria. The findings further discovered that the New Concept English for Junior Secondary Schools Books I, II and III illustrated different types of visual representativeness on the cover passages such as representational, organizational and transformational visuals of Junior students on the cover page, while the reading passages contain visual representativeness on the negative impact of the internet on children, the civil service and drug abuse respectively than other series. The Junior Project English for Secondary Schools Books I, II and III presented reading passages of less type of visual representativeness. All the textbook series presented visual representativeness on value orientation, family life, human right education, culture and entertainment. The visual representativeness was in line with the content of the curriculum to guide teachers and learners in teaching and learning process.

As per the degree of visual representativeness in the English language textbooks in use in Junior Secondary Schools in Ebonyi State of Nigeria, the result indicated that visual representativeness in the textbook series have some common features like in instances where we have visuals on school life, family, culture, agricultural practice and social vice. But there are short falls of visual representativeness as indicated in Tables 2a and 2b; Intensive English for J S.S 1,2 and 3 and New Concept English for J.S.S 1,2and 3 were found to have 85.7\%, 77.1\%, 70.5\% of visual representativeness 
respectively. While Junior Project English (books 1, 2, and 3) have less visual representiveness and high percentage of reading passages not illustrated visually to guide the students. The same textbook series have some reading passages having low percentage of visual representativeness. The table also indicated that New Concept English series have all the reading passages presented with visual representativeness. This textbook series illustrated holistic view of the society and the challenges facing the people of Nigeria. Thereby according the students the opportunities to observe, learn and have their own perception and conception of Nigeria society. This implies that New Concept English for Junior Secondary Schools 1, 2 and 3 and Intensive English for Junior Schools series have visual representativeness coverage of the reading passages and all the topics stipulated in the curriculum, while Junior Project English for Secondary Schools 1, 2 and 3 did not have visual representativeness of all the topics stipulated in the curriculum. Based on these findings, there seems to be an agreement between this and the assertion of Mahmood (2010) on the need to present issues in the curriculum holistically with the view to capturing the different aspects of life issues presented in the curriculum.

\section{Conclusion}

The pedagogical implication of this study is that adequate visual representations in junior secondary schools English language textbooks like Intensive English, New Concept English and Junior Project English can make learning more interesting and fun. These visuals should not just appear in the textbooks but they should be used for effective teaching of students. It is also necessary that both teachers and learners should use it. Teachers should always use it in teaching for students' retention of information and facts, and learners should equally use it to gather more vital information in learning.

Learning is an active activity that should not be passively done. In that regards, in every learning situation, there should be active interaction between the learner and the texts. By implication, learner may understand and gain knowledge easily and perform better in any given task that involves reading when exposed to child-centred strategy that is highly engaging. Visuals are engaging and learners are actively carried along in an engaging strategy such as this. Therefore, there is the need to adequately have visual representativeness in the Junior Secondary School English Textbooks, because the target audiences at this level of education are too hyperactive and often distracted with learning, hence the pedagogical implication of this study.

The study exposed the fact that some of the English language textbooks approved for teaching and learning of English language in Junior Secondary Schools in Ebonyi State did not accommodate current events of the society that will guide learners in learning the New Concept English for Junior Secondary School 1,2 and 3 series and Intensive English for Junior Secondary Schools 1, 2 and 3 are good in terms of visual representativeness coverage and current features in the society and should be maintained for teaching and learning by teachers and students. Junior project English for Junior Secondary Schools should be revised to ensure that the users get maximum knowledge and facts from the textbook. This will invaluably enhance students' performance in external examination. Based on the findings and conclusion of this study, the researcher made the following recommendations:

1. It is absolutely necessary that English language textbooks should be revised periodically with the intent of the content and the trend in the society to ensure better representational and transformational visuals. These types of visuals will facilitate the change that is demanded in students' performances in English language related courses in this $21^{\text {st }}$ century.

2. Textbook writers should ensure adequate visual representation in their textbooks based on the course contents as stipulated in the curriculum.

\section{References}

Boldeh, F. (2010). Mind your English. Gambia: Fulladu Publishers.

Ebonyi State Ministry of Education (2013). List of public secondary schools and their population. Abakaliki: PSR office.

Ebonyi State Ministry of Education (ESMOE) (2009). School data bank department of Secondary Education. Abakaliki, Ebonyi State.

Federal Ministry of Education (2007). 9 year Basic Education Curriculum English Studies for JSS1-3. Nigeria Educational Research and Developmental Council Ebonyi State Ministry

Grotjahn, R. (1987). On the methodological basis of introspective methods. In C. Færch and G. Kasper (eds.), Introspection in second language research. Clevedon Avon, England: Multilingual Matters.

Levie, W.H. (1987). Research on pictures: A guide to the literature. In Willows D. M. and Houghton H.A (Eds.). The psychology of illustration, (pp. 1-50). New York: Springer.

Mahmood K. (2010). Textbooks evaluation in Pakistan: Issues of conformity to the national curriculum guidelines. Bulletin of Education and Research 33(1) 15-36. 
Mayer R.E. (1994). Visual aids to Knowledge sensations from pictures and works. In W. Schnot and R.W Kulhavy (Eds), Comprehension: North Holland.

Mustapha, S. (2012). Gender equality in and through education in Nigeria: Gender representation in learning materials. Project Report, Unpublished Sheffield Hallam University

Nworgu, B. G. (1991). Educational research basic issues and methodology. Ibadan: Wisdom Publisher Ltd.

Ozongwu, C.N. (2011). Evaluation of junior secondary mathematics textbook in southeast zones of Nigeria. Master Degree Dissertation, submitted to Department of Science Education, University of Nigeria Nsukka.

Sipe, L.R. (1998). How pictorial books work: A semiotically framed theory of text-picture relationships. Children's Literature Education. 29, 97-108.

Udechukwu, R. (2004). Evaluation of the content of selected textbooks used for school certificate biology in Anambra State. International Journal of Education 2, 17-27.

West African School Certificate Examination (2013). WASCE Chief Examiners' Report.

West African School Certificate Examination (2015). WASCE Chief Examiners' Report. 